\title{
Efficacy of Cyclosporine A $0.05 \%$ in the Treatment of Patients with Dry Eye Syndrome
}

\author{
Kuru Göz Sendromlu Hastalarn Tedavisinde \%0,05 Siklosporin A'nnn Etkinliği
}

\section{Özge ŞEVIK1*(i), Özlem EVREN KEMER ${ }^{2}(\mathbb{D})$}

${ }^{1}$ Biga State Hospital, Clinic of Opthalmology, Çanakkale, Turkey

${ }^{2}$ Ankara State Hospital, Clinic of Opthalmology, Ankara, Turkey

\begin{abstract}
Dry eye is one of the most common ocular diseases in the elderly population and has increasing importance. Aging, decreased hormones and systemic autoimmunity are among the common causes of dry eye disease. Although the etiology of dry eye can change, it is known that the main cause is the inflammation in both lacrimal glands and ocular surfaces. To evaluate the effectiveness of topical cyclosporine A (CsA) $0.05 \%$ which is an immunemodulatory agent in the treatment of dry eyes, total of 51 patients with dry eye syndrome were included in our study. Forty-six of the patients were female while 5 patients were male. The mean duration of medication use of the patients was $8.72 \pm 3.59$ months (6-16 months). There was a statistically significant difference between the pre-treatment Schirmer scores and Schirmer scores found in 1st, 6 th and last month controls of Sjögren and Non-Sjögren groups $(p<0.05)$ while there was no statistically significant difference between Sjögren and Non-Sjögren groups $(p>0.05)$. In conclusion, it was found that there was a significant increase in Schirmer and fluorescein TBUT scores and tear meniscus height of both Sjögren and and Non- Sjögren groups.

Keywords: Dry eye, Cyclosporin A, Sjögren syndrome.
\end{abstract}

Öz: Kuru göz, yaşlı popülasyonda en sık görülen oküler hastalıklardan biridir ve önemi giderek artmaktadır. Yaşlanma, azalmış hormonlar ve sistemik otoimmünite kuru göz hastalı̆̆ının yaygın nedenleri arasındadır. Kuru göz etiyolojisi değişebilse de ana nedenin hem lakrimal bezlerde hem de oküler yüzeylerde inflamasyon olduğu bilinmektedir. Kuru gözün tedavisinde immün modülatör bir ajan olan topikal siklosporin A (CsA) \% 0,05'in etkinliğini değerlendirmek için toplam 51 kuru göz sendromu hastası çalışmaya dahil edildi. Hastaların 41'i kadın, 5'i erkekti. Hastaların ortalama ilaç kullanım süresi $8.72 \pm 3.59$ ay (6-16 ay) idi. Tedavi öncesi Schirmer skorları ile Sjögren ve Sjögren olmayan grupların 1., 6. ve son kontrollerinde bulunan Schirmer skorları arasında istatistiksel olarak anlamlı bir fark gözlendi $(\mathrm{p}<0.05)$. Sjögren ve Non- Sjögren grupları arasında ise anlamlı fark yoktu $(\mathrm{p}>0.05)$. Sonuç olarak hem Sjögren hem de Sjögren olmayan grupların Schirmer ve floresein TBUT skorlarında ve gözyaşı menisküs yüksekliğinde anlamlı bir artış olduğu bulundu.

Anahtar Kelimeler: Kuru göz, Siklosporin A, Sjogren sendromu.

${ }^{*}$ Corresponding author : Özge ŞEVİK

Geliş tarihi / Received : 24.04.2020

e-mail : ozgesevik@gmail.com

Kabul tarihi / Accepted: 19.08.2020

\section{Introduction}

Dry eye is one of the most common ocular diseases in the elderly population. Aging, decreased hormones and systemic autoimmunity (Sjögren's syndrome) are among the common causes of dry eye disease. Dry eye symptoms occurred due to Sjögren's syndrome affects approximately $1-2 \%$ of the population and more than $90 \%$ of patients are women (Bozkurt and Irkec, 2013; Brignole et al., 2000).
The etiopathology of dry eye has been understood recently. Although the etiology of dry eye can change, it is known that the main cause is the inflammation in both lacrimal gland and ocular surface (Perry, 2008). According to the current findings, it is believed that the ocular surface can be returned to a more normal state by breaking the inflammatory chain preventing $\mathrm{T}$ cell activation and cytokine production (De Paiva et al., 2019; Stevenson et al., 2000). 
It is thought that cyclosporine emulsion acts as a partial immunomodulator in patients having keratoconjunctivitis sicca associated with ocular inflammation and suppressed tear production (Sall et al., 2000). It has been demonstrated in the studies on surface conjunctival biopsy samples taken from dry eye patients where CsA suppressed the inflammatory process (Turner et al., 2000; Kunert et al., 2000).

In this study, he effectiveness of topical cyclosporine A (CsA) $0.05 \%$ which is an immunemodulatory agent in the treatment of dry eyes was investigated.

\section{Materials and Methods}

A total of 102 eyes of 51 patients (46 females, 5 males) who applied to Ankara Numune Training and Research Hospital 2nd Ophthalmology Department with dry eye complaints were included in the study. The study was carried out prospectively. The mean age of the patients was $49.9 \pm 11.01$ years. Twenty-nine patients were included in Sjögren group while 22 patients were in Non-Sjögren group. $54.9 \%$ of the patients were diagnosed as moderate, $23.5 \%$ mild and $19.6 \%$ severe dry eye. In the treatment, topical CsA $0.05 \%$ was applied as $2 \mathrm{x} 1 /$ day. The mean duration of medication use of the patients was $8.72 \pm 3.59$ months (6-16 months). The efficacy evaluation was based on the presence of punctate staining, fluorescein tear breakup time (TBUT), Schirmer test score and improvement in symptoms according to ODSI. Patients were evaluated three times in total as the $1^{\text {st }}$ month control, $6^{\text {th }}$ month control and last control.

Routine ophthalmic examination of patients including visual examination, intraocular pressure measurement and biomicroscopic examinations was carried out. The Ocular Surface Disease Index (OSDI), a subjective assessment scale to measure the degree of dry eye and its effect on visual function was used (Koksoy Vayısoğlu et al., 2019).

Having symptomatic dry eye disease despite standard treatment, Schirmer II test score of $\leq 15$ $\mathrm{mm} / 5$ secs, corneal and interpalpebral conjunctival staining, normal eyelid anatomy and blink function and corrected visual acuity of $\geq$ 20/100 (0.2) were determined as the criteria to be included in the study. Patients with active ocular infection, ocular rosacea, eyelid diseases such as entropion and ectropion, severe blepharitis or inflammation of the edges of eyelids, patients who used contact lens during the study, had ocular surface surgery or trauma in the previous 12 months (e.g. LASIK), patients with recurrent herpetic keratitis, pregnancy, breastfeeding history, uncontrolled systemic disease, medication use which may affect tear function such as systemic cyclosporin A, anticholinergic, antihistamine and diuretic in the previous 3 weeks were excluded from the study. Patients were divided into two groups: Patients of ANA (Antinuclear antibody) positivity, RA (Rheumatoid arthritis), SLE (Systemic lupus erythematosus), MKDH (Mixed connective tissue disease), SS (Systemic sclerosis), Primary Sjögren Syndrome were included in Sjögren Syndrome group while the others were included in Non-Sjögren dry eye group.

One drop artificial tear for 5 times a day and one drop of topical Cyclosporine $0.05 \%$ (Restasis, Allergan, Waco, TX) emulsion for 2 times a day with an interval of 12 hours were prescribed. Patients were observed minimum 6 months to maximum 16 months for an average of $8.72 \pm 3.59$ months.

Whatman No 41filter paper was used for the Schirmer II test. In order to evaluate the effect of medication on basal tear secretion, patients were tested after topical anesthesia (Proparacaine HCI) under dull illumination. In addition, patients were examined in terms of the presence of fluorescein TBUT, tear meniscus height and presence of corneal staining. Patients were investigated about their complaints and frequency of daily artificial tear drop use in the controls. SPSS statistical data analysis tool was used to evaluate all data statistically. 


\section{Results}

Results of the cyclosporine ophthalmic $0.05 \%$ emulsion treatment on 102 eyes of 51 dry eye patients were evaluated. Forty-six of the patients were female while 5 were male. The age of the patients ranged between 28 and 72 and average age was found as $49.9 \pm 11.01$ years. Patients were observed minimum 6 months to maximum 16 months, for an average of $8.72 \pm 3.59$ months. Twenty-nine patients were Sjögren and 22 patients were Non-Sjögren. Twenty-two patients in Sjögren group had RA (Rheumatoid arthritis), 2 patients had SLE (Systemic lupus erythematosus), 1 patient had primary Sjögren's syndrome, 1 patient had SS (Systemic sclerosis) and 3 patients had ANA (+) (Antinuclear antibody). Patients were divided into two groups as those who used the medication for 6 months and for 1 year or more. Thirty patients used the medication for 6 months and twenty patients for 12 months or more.

In addition to rheumatic diseases, 2 patients had GVH (Graft Versus Host) disease. The mean dry eye duration of the patients was $3.16 \pm 5.9$ years. This duration was minimum 6 months and maximum 10 years. The mean visual acuity corrected according to Snellen chart of the patients was $0.71 \pm 0.33$ before the cyclosporine $0.05 \%$ treatment, it was found $0.69 \pm 0.28$ after 6 months of treatment and was $0.67 \pm 0.27$ in the last control. The difference between the controls was not statistically significant $(\mathrm{p}>0.05)$. Intraocular pressure value was $16.8 \pm 5.1 \mathrm{mmHg}$ before the treatment, after 6 months of treatment it was found $17.9 \pm 6.8 \mathrm{mmHg}$ and it was $17.2 \pm$ $6.2 \mathrm{mmHg}$ in the last control. This change was not statistically significant $(\mathrm{p}>0.05)$.

In grouping patients according to OSDI score severity, it was found that most of the patients $(54.9 \%)$ was in the moderate dry eye group. Twelve patients $(23.5 \%)$ had mild dry eye disease and 10 patients $(19.6 \%)$ was severe dry-eyed.

There was a statistically significant difference between the pre-treatment Schirmer scores and Schirmer scores found in $1^{\text {st }}, 6^{\text {th }}$ and last month controls of Sjögren and Non-Sjögren groups $(p<0.05)$ while there was no statistically significant difference between Sjögren and Non-Sjögren groups ( $p>0.05)$. Comparing the Schirmer scores in the sixth month and last control ( $\geq 1$ year), it was found that there was no significant difference for the right eye in Sjögren group ( $p=0.252$ ) while the difference was significant in the Non-Sjögren group $(\mathrm{p}=0.050)$ (Table 1). The same comparison was made for the left eye and there was still no significant difference in the Sjögren group $(p=0.269)$ while there was a tendency of clinically and statistically significant difference in the NonSjögren group $(\mathrm{p}=0.057)$ (Table 2).

Table 1. Comparison of Schirmer values for the right eye of Sjögren and Non-Sjögren groups obtained in the controls

\begin{tabular}{lccll}
\hline Right Schirmer $\mathbf{( m m )}$ & Pre-treatment & 1. Month & 6. Month & Last \\
\hline Sjö̈ren & $4.8 \pm 3.5$ & $9.8 \pm 7.3$ & $11.7 \pm 5.6$ & $12.1 \pm 5.3$ \\
Non-Sjögren & $4.9 \pm 3.7$ & $9.7 \pm 4.7$ & $12.5 \pm 4.5$ & $16.2 \pm 6.3$ \\
Total & $4.9 \pm 3.6$ & $9.8 \pm 6.3$ & $12.1 \pm 5.1$ & $14.1 \pm 6.1$ \\
\hline
\end{tabular}

Table 2. Comparison of Schirmer values for the left eye of Sjögren and Non-Sjögren groups obtained in the controls

\begin{tabular}{lllll}
\hline Left Schirmer $\mathbf{( m m )}$ & Pre-treatment & 1. Month & 6. Month & Last \\
\hline Sjö̈ren & $5.06 \pm 3.06$ & $8.4 \pm 4.02$ & $11.5 \pm 4.9$ & $12.6 \pm 6.05$ \\
Non-Sjögren & $5.31 \pm 3.52$ & $10.3 \pm 4.2$ & $13.0 \pm 4.7$ & $15.4 \pm 5.3$ \\
Total & $5.1 \pm 3.2$ & $9.2 \pm 4.1$ & $12.1 \pm 4.8$ & $14.0 \pm 5.7$ \\
\hline
\end{tabular}


The change in fluorescein TBUT value in the $1^{\text {st }}$, $6^{\text {th }}$ and last month controls after the treatment is given in Table 3. In-group changes in the controls of both Sjögren and Non-Sjögren groups were statistically significant compared to pre-treatment values $(p<0.05)$ while there was no statistically significant difference between the groups $(\mathrm{p}>0.05)$.

Table 3. Tear BUT of Sjögren and Non-Sjögren groups in the controls

\begin{tabular}{lllll}
\hline FKZ (Secs) & Pre-treatment & 1. Month & 6. Month & Last \\
\hline Sjögren & $7.5 \pm 6.8$ & $22.0 \pm 11.9$ & $31.7 \pm 12.9$ & $36.8 \pm 12.0$ \\
Non-Sjögren & $8.18 \pm 7.02$ & $20.1 \pm 13.1$ & $31.6 \pm 10.4$ & $42.8 \pm 12.9$ \\
Total & $7.8 \pm 6.8$ & $21.2 \pm 12.3$ & $31.6 \pm 11.8$ & $39.8 \pm 12.5$ \\
\hline
\end{tabular}

In $38(74.5 \%)$ of patients, fluorescein staining was not observed when they first applied, whereas 13 $(25.5 \%)$ patients corneal punctate fluorescein staining. In the second control on the sixth month, staining disappeared both in two groups of patients. Considering the changes in controls, there was a significant change in the Sjögren group $(p<0.05)$ while it was not significant in the NonSjögren group ( $p>0.05)$. The difference between Sjögren and Non-Sjögren groups was not considered as statistically significant $(\mathrm{p}>0.05)$ (Table 4).

Table 4. Comparison of Sjögren and Non-Sjögren groups in terms of corneal staining according to controls

\begin{tabular}{lllllll}
\hline \multirow{2}{*}{ Corneal Staining } & \multicolumn{2}{l}{ Pre-treatment } & 1. Month & \multicolumn{3}{l}{ 6. Month } \\
\cline { 2 - 7 } & No & Yes & No & Yes & No & Yes \\
\hline Sjögren & $21(55.3 \%)$ & $8(61.5 \%)$ & $28(59.6 \%)$ & $1(33.3 \%)$ & $29(100 \%)$ & - \\
Non- Sjögren & $17(44.7 \%)$ & $5(38.5 \%)$ & $19(40.4 \%)$ & $2(66.7 \%)$ & $21(100 \%)$ & - \\
Total Patients & $\mathbf{3 8 ( 1 0 0 \% )}$ & $\mathbf{1 3 ( 1 0 0 \% )}$ & $\mathbf{4 7 ( 1 0 0 \% )}$ & $\mathbf{3 ( 1 0 0 \% )}$ & $\mathbf{5 0 ( 1 0 0 \% )}$ & - \\
\hline
\end{tabular}

There was no statistical difference between the Sjögren and Non-Sjögren groups comparing the tear meniscus height in terms of the changes in controls ( $p>0.05$ ).In both Sjögren and NonSjögren groups, improvement in $1^{\text {st }}$ control and $2^{\text {nd }}$ control was significant compared to pre-treatment $(\mathrm{p}<0.05)$ while the improvement in the last control was not significant compared to pre-treatment $(\mathrm{p}>0.05)$. This finding was associated with the decrease in the number of patients examined the last control (Table 5).

Table 5. Comparison of Sjögren and Non-Sjögren groups in terms of tear meniscus height according to controls

\begin{tabular}{lllll}
\hline & PT & 1. Month & 6. Month & Last \\
\hline Sjögren & & & & \\
$>\mathbf{0 . 3 m m}$ & $8(27.6 \%)$ & $17(58.6 \%)$ & $25(86.2 \%)$ & $9(90 \%)$ \\
$<\mathbf{0 . 3 m m}$ & $21(72.4 \%)$ & $12(41.4 \%)$ & $4(13.8 \%)$ & $1(10 \%)$ \\
\hline
\end{tabular}




\begin{tabular}{lllll}
\hline Non- Sjögren & & & & \\
$>\mathbf{0 . 3 m m}$ & $8(36.4 \%)$ & $16(\% 76.2)$ & $17(\% 81.0)$ & $8(80 \%)$ \\
$<\mathbf{0 . 3 m m}$ & $14(63.6 \%)$ & $5(\% 23.8)$ & $4(\% 19.0)$ & $2(20 \%)$ \\
\hline
\end{tabular}

Table 6. Comparison of OSDI score severity of Sjögren and Non-Sjögren groups in the first application and in the last control.

\begin{tabular}{lll}
\hline OSDI Score & First & Last \\
\hline Sjögren & $66.7 \pm 22.02$ & $40.48 \pm 25.26$ \\
Non-Sjogren & $64.3 \pm 15.9$ & $30.71 \pm 16.84$ \\
All Patients & $65.7 \pm 19.54$ & $36.3 \pm 22.45$ \\
\hline
\end{tabular}

The change in OSDI scores severity of the groups before and after the treatment was compared (Table 6). The change in controls compared to pre-treatment was statistically significant both in two groups $(p<0.05)$. There was no significant difference between the two groups $(\mathrm{p}>0.05)$.

There was also no significant difference between three groups created according to dry eye severity (Mild/ Moderate/ Severe) in terms of OSDI score percentage change $(p>0.05)$. However, the moderate dry eye group had the highest percentage of decrease (49.5\%) during the treatment. Considering the in-group changes, the percentage of decrease in patients of Sjögren and NonSjögren groups was respectively $41.3 \%, 42.1 \%$ in mild dry eye cases, $44.5 \%, 41 \%$ in moderate dry eye cases and $31.8 \%, 48 \%$ in severe dry eye cases.

Table 7. Statistical comparison of the Schirmer and fluorescein TBUT control scores with the first control scores of the patients grouped according to dry eye severity

\begin{tabular}{llll}
\hline Severity & 1. Month & 6. Month & Last \\
\hline Mild & $\mathbf{P}<\mathbf{0 . 0 0 8}$ & $\mathbf{P}<\mathbf{0 . 0 0 8}$ & $\mathrm{p}>0.008$ \\
Moderate & $\mathbf{P}<\mathbf{0 . 0 0 8}$ & $\mathbf{P}<\mathbf{0 . 0 0 8}$ & $\mathbf{P}<\mathbf{0 . 0 0 8}$ \\
Severe & $\mathrm{p}>0.008$ & $\mathbf{P}<\mathbf{0 . 0 0 8}$ & $\mathrm{p}>0.008$ \\
\hline
\end{tabular}

The results of the comparison of the Schirmer and fluorescein TBUT scores in the first application and controls in terms of dry eye severity were similar (Table 7). (Establishing Bonferroni correction, the same for right and left eye) In all moderate dry eye cases, the change observed in all controls compared to pre-treatment values was significant, whereas in mild dry eye cases, only the change in $1^{\text {st }}$ and $2^{\text {nd }}$ controls and in severe dry eye cases, only the change in $2^{\text {nd }}$ control was significant. The non-significance in the last control of patients with severe dry eye disease was explained by the decrease in the number of patients from 10 to 4.

The most common complaint among patients related to medication was burning. The rate of burning was $70.5 \%$ in the first control, while it decreased to $35 \%$ in the last control. Stinging, blurred vision, redness, eyelid swelling and pruritus were among other complaints.

Patients were recommended to use artificial tears $5 \times 1$ per day in addition to CsA $0.05 \%$ treatment. In the last control, only $47 \%$ of patients was using artificial tears with the same frequency.

\section{Discussion}

The mechanism contributing to improvement of dry eye disease is a cytokine and receptor-related inflammatory process. This hypothesis was supported by revealing lymphocytic infiltration (Pflugfelder and De Paiva, 2017; Foulks et al., 2015) and proinflammatory cytokines (Guan et al., 2017) in the lacrimal glands of patients with dry eye disease occurred due to autoimmune systemic disease (Sjögren’s syndrome).

Improvement in dry eye patients not having Sjögren's syndrome with CsA which is an immunomodulating agent suggested that dry eye may be a localized, cell-related inflammatory event (Ji et al., 2018). 
CsA exerts its immunomodulatory effect by inhibiting early events in T lymphocyte activation cascade (14). Deveci et al. observed improvement in symptoms such as redness, light sensitivity and pain in 26 patients with Sjögren's syndrome at the end of $1^{\text {st }}$ week and $1^{\text {st }}$ month of topical CsA $0.05 \%$ use, and a significant increase in fluorescein TBUT and Schirmer scores (Devec1 and Kobak, 2014). In the study carried out by Jain et al., NonSjögren dry eye patients showed a significant improvement $(28.5 \%)$ in subjective symptoms such as sandblasting with CsA 2\% prepared with olive oil, and an increase of $33 \%$ in Schirmer score was seen (Jain et al., 2007).

In a study on the reliability assessment of CsA ophthalmic $0.1 \%$ emulsion, 412 patients were observed for an average of 19.8 months and visual acuity decreased in $12.6 \%$ of the patients while it increased in $5.4 \%$ of them. This was explained by advanced age of patients and the emergence of other ocular defects. The increase of $0.18 \mathrm{mmHg}$ in IOP compared to pre-treatment was not accepted as significant (Barber et al., 2005). In our study, there was no significant change in both vision and IOP levels after the CsA $0.05 \%$ treatment.

In a study on 146 patients, dry eye patients were treated for 6 and 12 months, and an improvement in the OSDI score was observed in $72 \%$ of patients (Perry and Donnenfeld, 2004). There was more improvement in severe dry eye cases than other cases. In our study, the mean improvement rate in the OSDI score was $55.2 \%$ for all patients. Considering the severity, maximum improvement was observed in moderate cases with a rate of $49.5 \%$ while minimum improvement was observed in severe dry eye cases with a rate of $38.6 \%$.

Sall et al. (2000) investigated the efficacy and safety of cyclosporine in 877 moderate to severe dry eye patients (2 times a day for 2-6 months) and they found out that blurred vision $(\mathrm{p}<0.014)$, dry eye $(\mathrm{p}<0.001)$ and pruritus $(\mathrm{p}<0.038)$ improved significantly. In the same study, there was a significant increase in Schirmer test result and a significant decrease in corneal staining, blurred vision and frequency of artificial tear use $(\mathrm{p}<0.05)$. In our study, most improved complaint was sandblasting while the most resistant complaint to the medication was pruritus. Increase in Schirmer score and decrease in corneal staining, blurred vision, and decreased frequency in artificial tear use were similarly significant.

In Stern's study investigating the difference between conjunctival T-cell subpopulation in Sjögren's and Non-Sjögren syndrome, no difference was found between the two groups in terms of cellular immunoreactivity (Stern et al., 2002). The fact that there was not statistically difference between the two groups in terms of the improvement in Schirmer, fluorescein TBUT and OSDI scores can be associated with this.

In the study of Lelli et al. (2006), topical CsA treatment was started for 16 GVHD and the symptoms of 10 patients $(62.5 \%)$ improved, there was no change in the symptoms of 6 patients and 3 patients had burning and irritation. In our study, there were 2 cases with dry eye due to GVHD. In one of them, despite the current punctual occlusion treatment, punctate corneal staining and corneal filaments were observed. In both cases, staining was disappeared and there was a significant improvement in the Schirmer score after CsA treatment.

In CsA 0.05\% treatment, side effects are mostly mild and temporary (Jain et al., 2007). The most common side effect in our patients was burning and this ratio was $70.5 \%$ in $1{ }^{\text {st }}$ month control and decreased to $35 \%$ in the last control. The ratio of discontinuing medication due to side effects was $5.8 \%$ among patients.

In conclusion, it was found that there was a significant increase in Schirmer and fluorescein TBUT scores and tear meniscus height of both Sjögren and and Non-Sjögren groups in $1^{\text {st }}$ month, $6^{\text {th }}$ month and $1^{\text {st }}$ year after administering CsA $0.05 \%$ emulsion form. However, the fact that there was no statistical difference between the two groups supports the view that the main cause of dry eye is localized cellular inflammation in 
lacrimal gland. Quantitative improvement in parameters is a result of improving the underlying physiopathology of the disease. The improvement in moderate dry eye cases was more than the severe cases and this can be explained by the healthy tissue functioning in lacrimal gland which is less affected. In Sjögren group, medication use for one year and more did not provided a significant increase compared to 6 months use. Based on this finding, it may be suggested to use the medication for a maximum of 6 months in Sjögren cases. No medication-related severe ocular and systemic side effects were observed. Consequently, CsA is an effective formulation that maintains its currency and reliability in the treatment of dry eye until the effectiveness of other topical immunomodulatory agents is proven in the future.

\section{References}

Barber, L.D., Pflugfelder, S.C., Tauber, J., Foulks, G.N., 2005. Phase III safety evaluation of cyclosporine $0.1 \%$ ophthalmic emulsion administered twice daily to dry eye disease patients for up to 3 years. Ophthalmology 112(10), 1790-1794.

Bozkurt, B., Irkec, M., 2013. Kuru gözün fizyopatolojisi. Turkiye Klinikleri Journal of Ophthalmol-Special Topics 6(3), 1-7.

Brignole, F., Pisella. P.J., Goldschild, M., De Saint Jean, M., Goguel, A., Baudouin, C., 2000. Flow cytometric analysis of inflammatory markers in conjunctival epithelial cells of patients with dry eyes. Investigative Ophthalmology and Visual Science 41(6), 1356-1363.

De Paiva, C.S., Pflugfelder, S.C., Ng, S.M., Akpek, E.K., 2019. Topical cyclosporine A therapy for dry eye syndrome. Cochrane Database of Systematic Reviews 9(9) 10.1002/14651858.CD010051.

Devec1, H., Kobak, S., 2014. The efficacy of topical $0.05 \%$ cyclosporine A in patients with dry eye disease associated with Sjögren's syndrome. International Ophthalmology 34(5), 1043-1048.

Foulks, G.N., Forstot, S.L., Donshik, P.C., Forstot, J.Z., Goldstein, M.H., Lemp, M.A., Nelson, J.D., Nichols, K.K., Pflugfelder, S.C., Tanzer, J.M., Asbell, P., Hammitt, K., Jacobs, D.S., 2015. Clinical guidelines for management of dry eye associated with sjögren disease. The Ocular Surface 13(2), 118-32.
Guan, Q., Gao, X., Wang, J., Sun, Y., Shekhar, S., 2017. Cytokines in Autoimmune Disease. Mediators of Inflammation 2017, 1-2.

Jain, A.K., Sukhija, J., Dwedi, S., Sood, A., 2007. Effect of topical cyclosporine on tear functions in teardeficient dry eyes. Annals of Ophthalmology (Skokie) 39(1), 19-25.

Ji, Y.W., Lee, J.L., Kang, H.G., Gu, N., Byun, H., Yeo, A., Noh, H., Kim, S., Choi, E.Y., Song, J.S., Lee, H.K., 2018. Corneal lymphangiogenesis facilitates ocular surface inflammation and cell trafficking in dry eye disease. The Ocular Surface 16(3), 306-313.

Köksoy Vayısoğlu, S., Ơncü, E., Dursun, Ơ., Dinc, E., 2019. Investigation of dry eye symptoms in lecturers by ocular surface disease index. Turkish Journal of Ophthalmology 49(3),142-148.

Kunert, K.S., Tisdale, A.S., Stern, M.E., Smith, J.A., Gipson, I.K., 2000. Analysis of topical cyclosporine treatment of patients with dry eye syndrome: effect on conjunctival lymphocytes. Archives of Ophthalmology 118(11), 1489-1496.

Lelli, G.J., Much, D.C., Gupta, A., Farjo, Q.A., Nairus, T.M., Mian, S.I., 2006. Ophthalmic cyclosporine use in ocular GVHD. The Journal of Cornea and External Disease 25(6), 635-638.

Perry, H.D., 2008. Dry Eye Disease: Pathophysiology, classification, and diagnosis. The American Journal of Managed Care 14 (3), 79-87.

Perry, H.D., Donnenfeld, E.D., 2004. Dry eye diagnosis and management in 2004. Current Opinion in Ophthalmology 15(4), 299-304.

Pflugfelder, S.C., De Paiva, C.S., 2017. The pathophysiology of dry eye disease: what we know and future directions for research. Ophthalmology 124(11S), 4-13.

Sall, K., Stevenson, O.D., Mundorf, T.K., Reis, B.L., 2000. Two multicenter, randomized studies of the efficacy and safety of cyclosporine ophthalmic emulsion in moderate to severe dry eye disease. CsA phase 3 study group. Ophthalmology 107(5), 631-639.

Stern, M.E., Gao, J., Schwalb, T.A., Ngo, M., Tieu, D.D., Chan, C., Reis, B.L., Whitcup, S.M., Thompson, D., Smith, J.A., 2002. Conjunctival T-cell subpopulations in Sjogren's and non-Sjogren's patients with dry eye. Investigative Ophthalmology and Visual Science 43(8), 2609-2614.

Stevenson, D., Tauber, J., Reis, B.L., 2000. Efficacy and safety of cyclosporin A ophthalmic emulsion in the 
treatment of moderate-to-severe dry eye disease: a dose-ranging, randomized trial. The cyclosporin a phase 2 study group. Ophthalmology 107(5), 967-974.

Turner, K., Pflugfelder, S.C., Ji, Z., Feuer, W.J., Stern, M., Reis, B.L., 2000. Interleukin-6 levels in the conjunctival epithelium of patients with dry eye disease treated with cyclosporine ophthalmic emulsion. The Journal of Cornea and External Disease 19(4), 492-496.
White, D.E., Zhao, Y., Jayapalan, H., Machiraju, P., Periyasamy, R., Ogundele, A., 2020. Treatment satisfaction among patients using anti-inflammatory topical medications for dry eye disease. Clinical Ophthalmology 14, 875-883. 